\title{
Impact of coelenterate predation on larval plaice Pleuronectes platessa and flounder Platichthys flesus stock in the western Wadden Sea
}

\author{
H. W. van der Veer \\ Netherlands Institute for Sea Research, P. O. Box 59, 1790 AB Den Burg, Texel, The Netherlands
}

\begin{abstract}
During the seasonal immigration of plaice and flounder larvae into the Dutch Wadden Sea in spring, the coelenterates Pleurobrachia pileus L. and Aurelia aurita L. have been positively identified as predators of both flatfish species. Evidence for a causal relation between outbursts of the predatory coelenterates and the observed abrupt termination of larval flatfish immigration is found in (1) the coincidence of increases in coelenterate numbers and decreases in larval densities, (2) positive observations of larval flatfish in coelenterate stomach contents, (3) a comparison between food demand of the coelenterate population and standing stock of the pelagic food resource at that time. Impact of this predation on plaice recruitment is expected to be small, since most larvae have already completed their immigration into the Wadden Sea when the coelenterate outburst starts. Although the coelenterate outburst occurs at about the same time every year, their predation may have a density-dependent component, since the timing of plaice immigration seems to be related to abundance, with larger yearclasses arriving later than smaller ones. For flounder larvae the impact will be greater, because of the shorter period of immigration and the coincidence between coelenterate outburst and maximum flounder abundance.
\end{abstract}

\section{INTRODUCTION}

Spawning of both plaice Pleuronectes platessa L. and flounder Platichthys flesus L. takes place from about December until March in the deeper and more saline parts of the southern North Sea (Harding et al. 1978). The developing eggs and larvae are transported by residual currents towards the coastal zone (Houghton \& Harding 1976, Talbot 1976, 1978), from where the larvae migrate into the nursery areas (Creutzberg et al. 1978). Inside the nursery areas, of which the Wadden Sea is probably the most important one (Creutzberg \& Fonds 1971, Zijlstra 1972), the larvae settle, mainly on the tidal flats (Bergman et al. 1980).

During transport from the spawning grounds towards the nurseries, the eggs and larvae suffer a heavy mortality, and their numbers are severely reduced (Harding et al. 1978). This mortality may be caused by either predation on the drifting eggs and larvae, or starvation of the larvae. Herring has been shown to prey selectively on plaice eggs, although it seems unlikely that this species represents the main cause of mortality (Daan 1976, Daan et al. 1984).
Coelenterates are also numerous, and known as potential predators. However, Tungate (1975) found that in the open sea their development starts too late to consider them significant predators on flatfish larvae, and plaice in particular.

In coastal waters the situation may be different since the larvae reach these areas 1 or 2 mo later. According to previous studies, larval immigration ends abruptly every year at the beginning of May (Creutzberg et al. 1978), while at the same time an outburst of coelenterates occurs near the Wadden Sea inlets (van der Baan $1980 \mathrm{a}, \mathrm{b}, \mathrm{c})$. Among these coelenterates several species (e.g. the ctenophore Pleurobrachia pileus, the scyphomedusa Aurelia aurita and the hydromedusae Sarsia tubulosa and Eutonina indicans) are known as potential predators of fish larvae, under laboratory (Fraser 1969, Greve 1972, Arai \& Hay 1982, Bailey \& Batty 1983, Bailey 1984) or natural conditions (Möller 1980b, 1984, Arai \& Hay 1982).

In this study attention is paid to the possible impact of coelenterate predation on the late pelagic larval stages of plaice and flounder entering the Wadden Sea nursery area. The following 3 questions are discussed: 
(1) Is there any proof of significant predation by coelenterates on flatfish larvae in the area? (2) Can the sudden break-down in the immigration of flatfish larvae be due to predation by coelenterates? (3) How large can the impact be of coelenterate predation on larval stocks of these 2 flatfish species?.

\section{MATERIAL AND METHODS}

From February to June in 1980, 1981, and 1982 , samples were taken in a number of tidal gullies (5 to 10 $m$ depth) surrounding a major settling area for flatfish larvae, the Balgzand, at the main entrance of the western part of the Dutch Wadden Sea (Fig. 1).

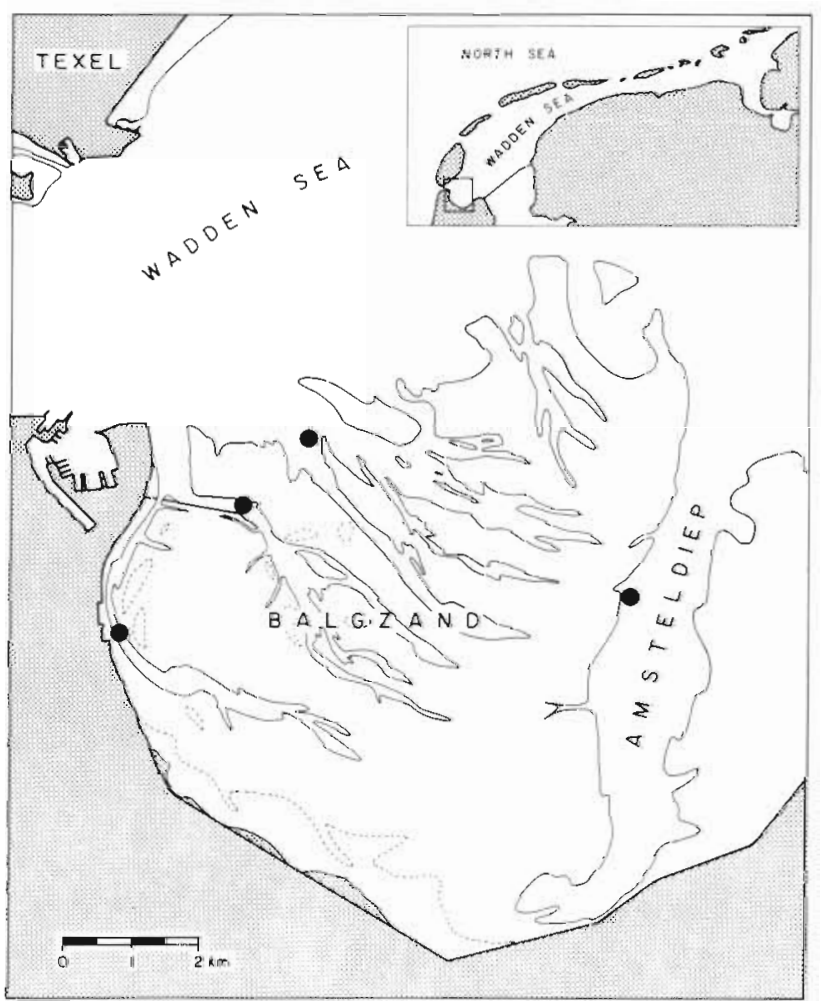

Fig. 1. Map of western part of Dutch Wadden Sea. Sampling stations (O) are indicated

Depending on weather conditions, from 1 to 4 tidal cycles were sampled per week, mostly during daytime but also partly during night-time. During each flood and ebb tide at least 5 double-oblique hauls were made at current velocities of over $20 \mathrm{~cm} \mathrm{~s}^{-1}$ The nets were made of polyamid plankton gauze (Monodur no. $2000,2 \mathrm{~mm}$ aperture) with an opening of $0.7 \mathrm{~m}^{2}$ and a length of $5 \mathrm{~m}$. The amount of water passing through the net was measured with a flow-meter mounted in the mouth of the net. The porosity $(0.59)$ and the mesh area $\left(12 \mathrm{~m}^{2}\right)$ of the net (definitions according to Smith et al.
1968) were large enough to prevent any serious clogging and overflow even during the spring bloom of the algae Phaeocystis pouchetii. The general reduction of water flow through the net was about $10 \%$ and independent of current velocity. However, during and after the bloom of $P$. pouchetii, this reduction increased to about $30 \%$ (van der Veer \& Sadée 1984). Depending on current velocity, haul duration varied from 10 to $45 \mathrm{~min}$ and sample size between 300 and $2000 \mathrm{~m}^{3}$ water filtered.

After the net washdown, all material was preserved in a $4 \%$ formalin seawater solution and afterwards sorted in the laboratory. Flatfish larvae were classified according to $\mathrm{mm}$ total length classes. No correction was made for shrinkage, since both Lockwood (1973) and Dapper (1978) found that, at least for plaice, shrinkage in $4 \%$ formaldehyde was negligible. Either the total catch or a subsample of the coelenterates, with the exception of Aurelia aurita specimens larger than $4 \mathrm{~cm}$ diameter, was put into a flat basin and photographed on slides. From these slides, numbers of the various species were counted on a projection screen. From each catch approximately 100 individual Pleurobrachia pileus were measured in $\mathrm{mm}$ classes, allowing a correction for shrinkage of $20 \%$ for all size classes (van der Veer \& Sadée 1984). A. aurita specimens smaller than $4 \mathrm{~cm}$ were treated in the same way, allowing $10 \%$ shrinkage for all size classes (van der Veer \& Oorthuysen 1985), whereas the larger specimens were measured alive to the nearest $0.5 \mathrm{~cm}$ below. Sizes of the umbrellas of Sarsia tubulosa and Eutonina indicans were not recorded. Subsamples were fixed for stomach content analysis.

No correction was made for net efficiency. The relatively small swimming speed of the larvae (Bailey 1984) and of the coelenterates compared to the high current velocities during fishing - up to $120 \mathrm{~cm} \mathrm{~s}^{-1}$ (van der Veer \& Sadée 1984) - and the low reduction of water flow through the net both suggest that net avoidance does not seem likely. Moreover, plaice and flounder larvae caught during daytime showed an almost equal size distribution to those caught during the subsequent night (Table 1). In the case of an increasing net avoidance with length, a larger mean length during night-time would be expected. All flatfish and coelenterate data were expressed in numbers of individuals per $1000 \mathrm{~m}^{3}$ (ind $1000 \mathrm{~m}^{-3}$ ) and arithmetic mean densities were calculated for each week.

The variance consistently surpassed the arithmetic mean by a large margin for all species, which pointed to uneven distributions in the water mass. For such distributions, confidence limits can be computed by using the factors derived from a $\log (x+1)$ transformation and applying them to the arithmetic mean of the samples (Elliot 1977). For $95 \%$ confidence limits, these 
Table 1. Mean size distribution of plaice and flounder larvae caught during day- and subsequent night-time in 1981

\begin{tabular}{|c|c|c|c|c|}
\hline \multirow{2}{*}{$\begin{array}{l}\text { Size } \\
(\mathrm{mm})\end{array}$} & \multicolumn{2}{|c|}{ No. of plaice } & \multicolumn{2}{|c|}{ No. of flounder } \\
\hline & Day & Night & Day & Night \\
\hline 6 & - & - & 37 & 24 \\
\hline 7 & 1 & 1 & 145 & 115 \\
\hline 8 & 1 & 2 & 131 & 52 \\
\hline 9 & 9 & 15 & 11 & 1 \\
\hline 10 & 20 & 24 & - & - \\
\hline 11 & 5 & 7 & - & - \\
\hline 12 & 2 & 2 & - & - \\
\hline Mean & 10.3 & 9.9 & 7.8 & 7.7 \\
\hline
\end{tabular}

factors of the Student's t distribution ranged between 2.09 and 2.02, depending on the number of hauls made ( 20 to 40 ). Therefore, the $95 \%$ confidence limits would lie between 47 and $209 \%$ of the mean.

Part of the results concerning Pleurobrachia pileus and Aurelia aurita have already been published (van der Veer \& Sadée 1984, van der Veer \& Oorthuysen 1985).

Stomach contents of coelenterates were examined in preserved material weekly in 1981 and 1982.

\section{RESULTS}

\section{Flatfish larvae}

Fig. 2 shows the abundances of flatfish larvae in the plankton as a weekly average over all sampling stations in 1980, 1981 and 1982. Plaice larvae were present from the beginning of March in these years. Densities increased in March and April to peak numbers of about 8 to 18 ind $1000 \mathrm{~m}^{-3}$. In all years a sharp decrease in numbers occurred at the end of April, resulting in a nearly complete absence after the beginning of May. The total duration of plaice larval immigration was restricted to March and April. Weekly mean length of the larvae fluctuated slightly in all $3 \mathrm{yr}$,
Fig. 2. Pleuronectes platessa and Platichthys flesus. Mean tidal abundance (ind $1000 \mathrm{~m}^{-3}$ ) and mean length $(\mathrm{mm})$ of pelagic plaice $(-)$ and flounder (-- ) larvae near the entrance of the Wadden Sea in 1980, 1981 and 1982, based on 20 to 40 hauls per week
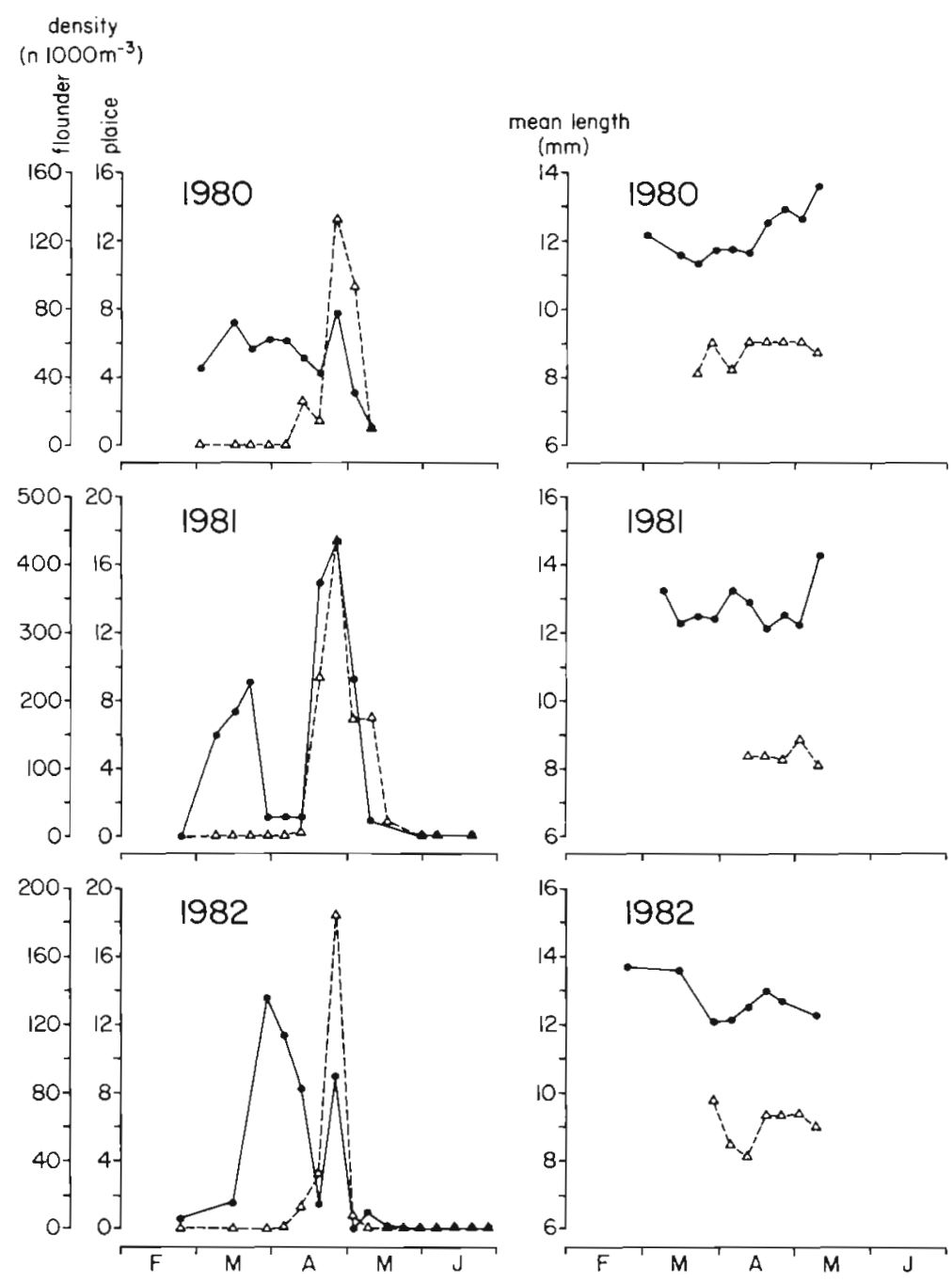
between 12 and $14 \mathrm{~mm}$, without consistent trends between years.

The first flounder larvae arrived about 1 mo later than plaice; in none of the $3 \mathrm{yr}$ was this before the beginning of April. Maximum numbers of flounder larvae were considerably higher than those of plaice: 135 to 450 ind $1000 \mathrm{~m}^{-3}$. As for plaice, densities of flounder larvae showed a sharp decrease at the end of April leading to complete absence from the beginning of May. In contrast to plaice, the immigration of flounder was restricted to about 1 mo. The mean length of the larvae was on average about 8 to $9 \mathrm{~mm}$, and always significantly smaller than the mean length of the plaice larvae.

\section{Coelenterate species}

The ctenophore Pleurobrachia pileus showed low abundances until mid-April in all 3 yr (Fig. 3). In the second half of April numbers started to increase slowly, but it was not until the end of April that an outburst was observed up to maximum numbers of between 14000 and 17000 ind $1000 \mathrm{~m}^{-3}$. After this peak, densities dropped sharply to less than 1000 ind $1000 \mathrm{~m}^{-3}$ at the end of June. Mean diameter increased over the period of observation from about $4 \mathrm{~mm}$ in March up to $12 \mathrm{~mm}$ in June.

The abundance of the scyphomedusa Aurelia aurita showed a similar development in 1981 and 1982 (Fig. 4). After being absent up to the end of April, its numbers increased sharply to maxima of 200 to 500 ind $1000 \mathrm{~m}^{-3}$. Thereafter densities declined to a low level. Average bell size increased in both years from $2 \mathrm{~cm}$ in April to 16 to $24 \mathrm{~cm}$ in June.

The hydromedusae found in 1981 and 1982 were Sarsia tubulosa and Eutonina indicans, both appearing at the end of April (Fig. 5). Their patterns of abundance closely resembled those of Pleurobrachia pileus and Aurelia aurita, with peak densities of 2500 to 5500 ind $1000 \mathrm{~m}^{-3}$ for $S$. tubulosa and 22 ind $1000 \mathrm{~m}^{-3}$ for $E$.
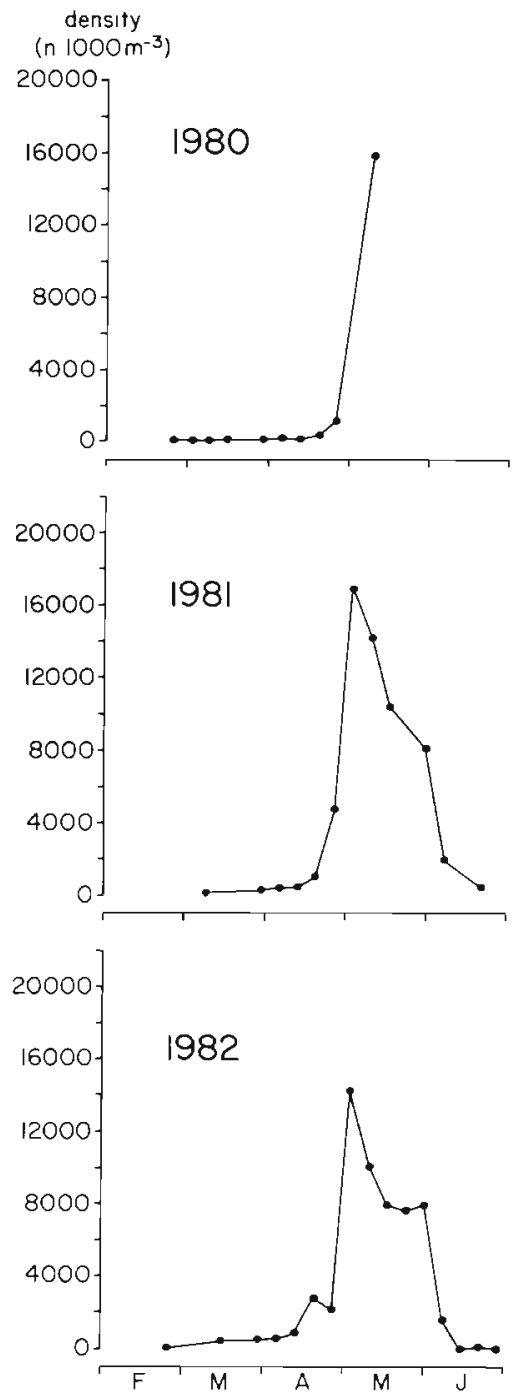
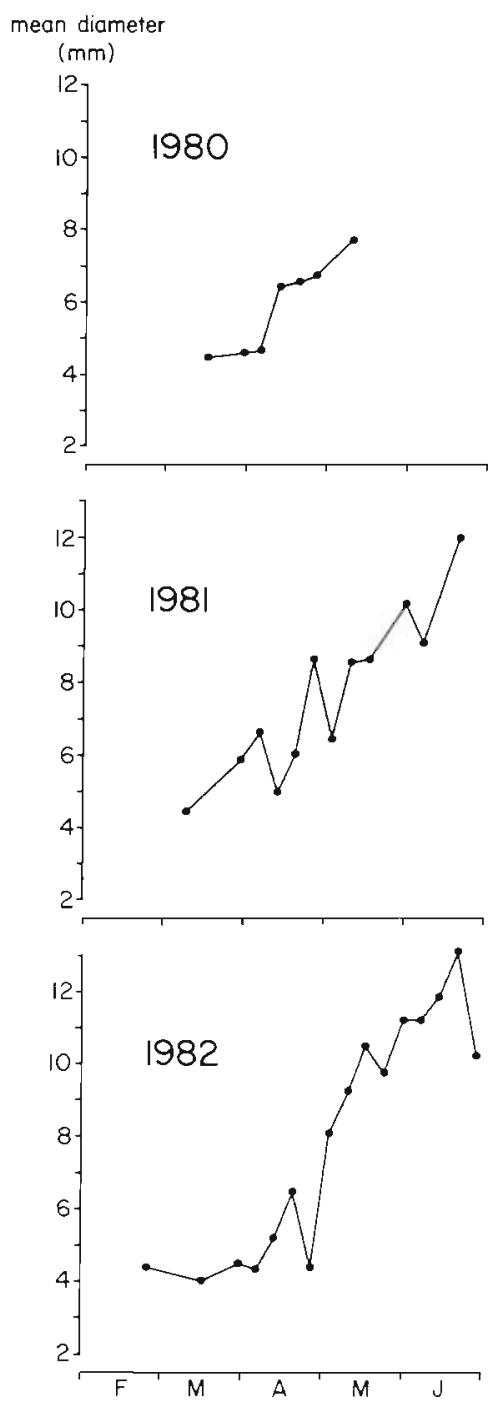

Fig. 3. Pleurobrachia pileus. Mean tidal abundance (ind $1000 \mathrm{~m}^{-3}$ ) and mean diameter (mm) near the entrance of the Wadden Sea during larval flatfish immigration in 1980, 1981 and 1982 , based on 20 to 40 hauls per week 
Fig. 4. Aurelia aurita. Mean tidal abundance (ind $1000 \mathrm{~m}^{-3}$ ) and mean bell size $(\mathrm{cm})$ near the entrance of the Wadden Sea during larval flatfish immigration in 1981 and 1982, based on 20 to 40 hauls per week

Fig. 5. Sarsia tubulosa and Eutonina indicans Mean tidal abundance (ind $1000 \mathrm{~m}^{-3}$ ) near the entrance of the Wadden Sea during larval flatfish immigration in 1981 and 1982 based on 20 to 40 hauls per week
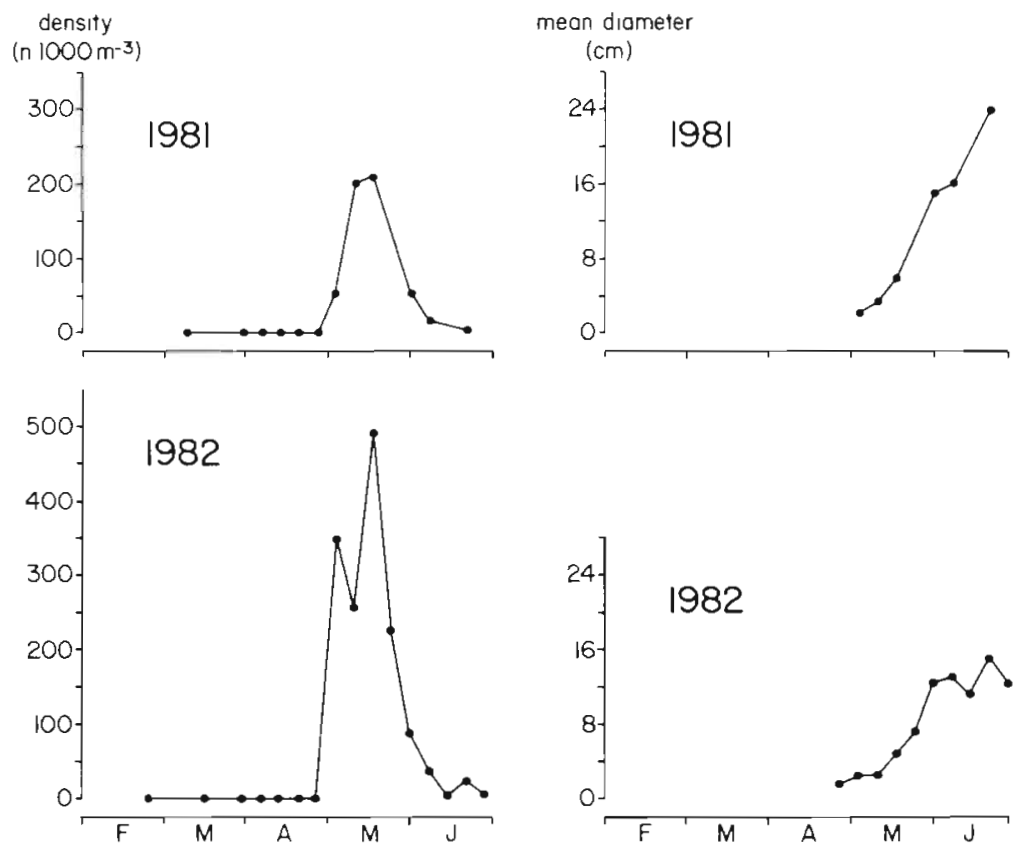

Sorsia tubuloso

Eutonid indicans

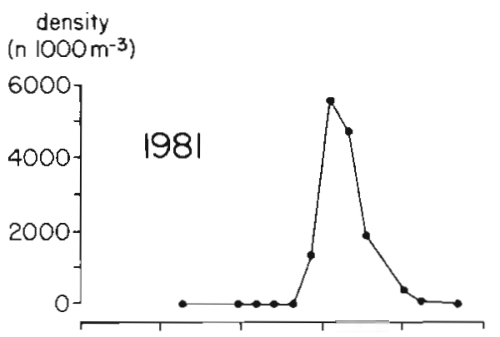

density

(n $1000 \mathrm{~m}^{-3}$ )
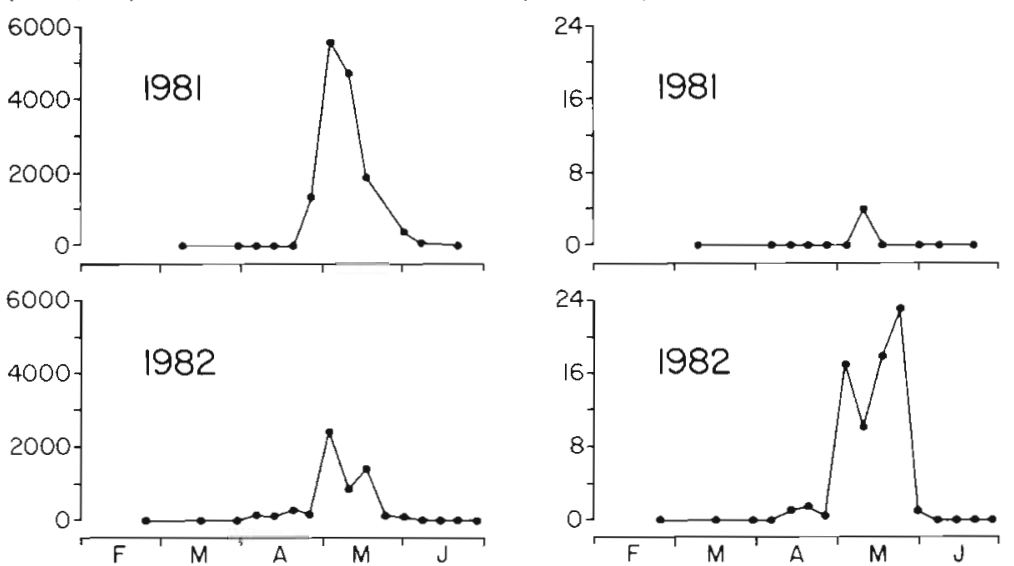

indicans. In 1981 hardly any E. indicans were found up to the end of June.

\section{Stomach content analysis}

Table 2 summarizes all data obtained on the stomach contents of preserved coelenterates in 1981 and 1982. Predation on flatfish larvae was positively identified in both Pleurobrachia pileus and Aurelia aurita. With 1 exception, only flounder larvae were found. Possible regurgitation of stomach content during preservation was investigated for Pleurobrachia pileus. 200 individuals were checked before and after fixation on a $4 \%$ formalin solution. The percentage of animals with a full stomach decreased from 66 to $4 \%$ after fixation, which means that $95 \%$ of the $P$. pileus had lost their stomach content.

\section{DISCUSSION}

The role of both ctenophores and medusae as carnivores among the macroplankton is well established. Their rapid population growth and mass occurrence can only be understood by the exertion of a heavy predation on the zooplankton community (Kremer 1976, Möller 1980a). Their diet spectrum is wide and 
Table 2. Numbers of flatfish larvae detected in the stomachs of preserved coelenterates in 1981 and 1982. N: number of stomachs observed (roughly estimated); $n$ : number of flatfish larvae observed; f: flounder; p: plaice

\begin{tabular}{|c|c|c|c|c|c|c|c|c|}
\hline \multirow[t]{2}{*}{ Date } & \multicolumn{2}{|c|}{ Pleurobrachia pileus } & \multicolumn{2}{|c|}{ Aurelia aurita } & \multicolumn{2}{|c|}{ Sarsia tubulosa } & \multicolumn{2}{|c|}{ Eutonina indicans } \\
\hline & $N$ & n & $N$ & $\mathrm{n}$ & $N$ & $\mathrm{n}$ & $\mathrm{N}$ & $\mathrm{n}$ \\
\hline \multicolumn{9}{|l|}{1981} \\
\hline 20-24 Apr & 2000 & $1(\mathrm{f})$ & - & - & 300 & 0 & - & - \\
\hline 27 Apr-1 May & 3000 & $2(\mathrm{f})$ & 50 & 0 & 400 & 0 & - & - \\
\hline 4-8 May & 3000 & $2(\mathrm{f})$ & 50 & $1(\mathrm{f})$ & 400 & 0 & - & - \\
\hline 11-15 May & 3000 & 2 (f) & 200 & 0 & 600 & 0 & - & - \\
\hline \multicolumn{9}{|l|}{1982} \\
\hline 26 Apr-1 May & 2000 & $1(\mathrm{f})$ & 150 & $1(p)$ & 200 & 0 & 40 & 0 \\
\hline 3-8 May & 2000 & 1 (f) & 150 & 0 & 200 & 0 & 40 & 0 \\
\hline
\end{tabular}

varies considerably between species. Some, e.g. the ctenophores Beroë gracilis and B. cucumis, feed exclusively on other coelenterates (Greve 1970), while other species seem to prefer copepods, barnacle larvae or fish larvae (Lebour 1922, 1923).

Evidence for fish predation by coelenterates is provided by a number of authors (Table 3). Most of the experimental work has been carried out with Aurelia aurita, and indicates that a number of fish larvae may fall prey to these species. Under natural conditions fish predation by coelenterates has also been observed, however mostly from preserved samples. Predation on plaice or flounder larvae has only been reported for Pleurobrachia pileus by Lebour (1923) and for A. aurita by Lebour (1923), Fraser (1969), Bailey \& Batty (1983) and Bailey (1984).
Coelenterate predation on flatfish larvae in the open sea during drifting from the spawning grounds to the coastal nursery does not seem very likely. Tungate (1975) found, that at the time of the spring outburst of coelenterates, the patch of plaice larvae had already drifted towards the coastal zone. A comparison of the abundances of flatfish larvae and of coelenterates near the entrance to the Wadden Sea shows a different picture for the coastal area. At the end of April and the beginning of May plaice and flounder larvae immigrate in large numbers until the explosive increase of the various coelenterate species occurs, both in numbers and - since the increase in numbers is associated with increases in mean size - even more in biomass. Here, coelenterate predation on flatfish larvae seems a realistic possibility.

Table 3. Literature review of coelenterates known as potential fish predators and present in the coastal zone of the southern North Sea (van der Baan 1980a, b, c, this study) under laboratory and natural conditions

\begin{tabular}{|c|c|c|c|}
\hline Species & Prey & Condition & Source \\
\hline \multicolumn{4}{|l|}{ Ctenophores } \\
\hline \multirow[t]{2}{*}{ Pleurobrachia pileus } & Sole & Laboratory & Greve 1972 \\
\hline & Plaice, herring & Natural & Lebour 1923 \\
\hline \multicolumn{4}{|l|}{ Scyphomedusae } \\
\hline \multirow[t]{9}{*}{ Aurelia aurita } & Fish eggs and larvae & Laboratory & Lebour 1922 \\
\hline & Cod, flounder & Laboratory & Fraser 1969 \\
\hline & Herring & Laboratory & Arai \& Hay 1982 \\
\hline & Herring & Laboratory & Bailey \& Batty 1983 \\
\hline & Plaice, herring, & & \\
\hline & flounder, turbot & Laboratory & Bailey \& Batty 1983 \\
\hline & $\begin{array}{l}\text { Plaice, flounder, cod, } \\
\text { herring, turbot }\end{array}$ & Laboratory & Bailey 1984 \\
\hline & Flatfishes & Natural & Lebour 1923 \\
\hline & Herring & Natural & Möller $1980 \mathrm{~b}$ \\
\hline \multicolumn{4}{|l|}{ Hydromedusae } \\
\hline \multirow{2}{*}{ Sarsia tubulosa } & Herring & Laboratory & Arai \& Hay 1982 \\
\hline & Herring & Natural & Arai \& Hay 1982 \\
\hline Eutonina indicans & Herring & Laboratory & Arai \& Hay 1982 \\
\hline \multirow[t]{2}{*}{ Phialidium hemisphericum } & Sole, other species & Laboratory & Lebour 1922 \\
\hline & Herring, sprat & Natura! & Lebour 1923 \\
\hline Rathkea octopunatata & Herring, sprat & Natural & Lebour 1923 \\
\hline
\end{tabular}




\section{Coelenterate predation on flatfish larvae}

Direct observations of attack and subsequent consumption of flatfish larvae under field conditions yield the best proof of predation. However, in estuarine areas such as the Wadden Sea, characterized by strong tidal currents and high turbidity (Postma 1954), such observations are practically unobtainable. Therefore, this study attempts to demonstrate predation by means of stomach content analysis of various potential predators, i.e. the coelenterate species. Such a stomach content analysis can be hampered by a number of factors which may bias the results, e.g. (1) feeding on flatfish larvae within the net during fishing and net handling; (2) regurgitation of stomach contents during net handling or fixation; (3) digestion of food remains before coelenterates were killed; (4) identification problems in the case of partly digested stomach contents.

Feeding of coelenterates during plankton hauls does not seem likely, because most of the fish larvae ingested were already partly digested. Regurgitation did occur in this study during fixation of Pleurobrachia pileus, although other investigators (Seip \& Seip-Ottema 1981) did not find such an effect. In this study, regurgitation may be considered an important factor, which results in an underestimation of the predation rate by a factor of 20. For Aurelia aurita and the 2 hydromedusae no such data are available. Digestion time of fish larvae in $P$. pileus seems to be of the order of a few hours (Reeve \& Walter 1978). Since net handling took about $15 \mathrm{~min}$ digestion can be considered an insignificant factor as compared to regurgitation. A further bias in the results may be related to identification problems of partly digested fish larvae. This will also lead to underestimation of actual predation pressure.

The problem of regurgitation together with the low ratio of fish larva to potential predator abundance at the time of the coelenterate outburst (approximately 1 flatfish larva to 100 coelenterates) make the chances of observing larvae in coelenterate stomachs very small. Nevertheless, in 1981 and 1982 respectively, 7 and 2 flatfish larvae were identified in stomachs of Pleurobrachia pileus and Aurelia aurita. No larvae were found in the stomachs of the hydromedusae species.

Table 4. Number of flatfish larvae detected in stomachs of living Pleurobrachia pileus in 1984. p: plaice; f: flounder

\begin{tabular}{|ccc|}
\hline Date & $\begin{array}{c}\text { No. of } P \text {. pileus } \\
\text { examined }\end{array}$ & $\begin{array}{c}\text { No. of larvae } \\
\text { detected }\end{array}$ \\
\hline 23 Apr & 270 & $1(\mathrm{p})$ \\
7 May & 445 & $12(\mathrm{f})$ \\
\hline
\end{tabular}

These scarce results show, be it qualitatively, that coelenterate predation on flatfish larvae does occur in the coastal zone near the Wadden Sea at the end of April and the beginning of May. The species consuming plaice and flounder larvae in this study correspond with those mentioned by Lebour (1923).

\section{Effects of coelenterate predation on flatfish immigration}

Actual predation by coelenterates may be much higher than is suggested from stomach content analysis. Due to underestimations caused by regurgitation and identification problems, at least $20 \times 9=180$ flatfishes will in fact have been consumed by the 15000 Pleurobrachia pileus investigated (Table 2), which means predation by about $1 \%$ of the ctenophores within the digestion time i.e. a few hours (Reeve \& Walter 1978). Analysis of freshly caught, not preserved, material in early May 1984 showed as expected even more larvae in $P$. pileus stomachs: 12 flatfish larvae in 445 living ctenophores at an abundance of 18 plaice and 215 flounder larvae $1000 \mathrm{~m}^{-3}$. This means that $2.5 \%$ of the $P$. pileus population had consumed a flatfish larva shortly before collection (Table 4). Converted to the total population of about 14000 ind $1000 \mathrm{~m}^{-3}$ at the beginning of May, this would mean a predation of at least 140 flatfish larvae $1000 \mathrm{~m}^{-3}$ per few hours, based on stomach content analysis of preserved samples (corrected for regurgitation only), and of 350 larvae $1000 \mathrm{~m}^{-3}$ based on analysis of freshly caught animals. In both cases it implies a total removal of all flatfish larvae by $P$. pileus within the time needed for digestion. Moreover other coelenterates, at least Aurelia aurita, would also contribute to the consumption of flatfish larvae.

The effect of coelenterate predation is also indicated by the coincidence between the coelenterate outburst and larval depletion. During all 3 yr of this study, the sharp increase in numbers of coelenterates coincided with a dramatic drop in flatfish numbers. Creutzberg et al. (1978) reported that in earlier years $(1974,1975$ and 1977), larval plaice immigration stopped at the same time of year. Although coelenterates were not quantified at that time, qualitative observations pointed to coincident outbursts of Pleurobrachia pileus (Creutzberg pers. comm.).

A comparison of consumption rates of predatorial coelenterates with biomasses of flatfish larvae and other food items may be another indirect way to assess whether coelenterate predation might be responsible for the abrupt break-down in larval abundance. Consumption figures of Pleurobrachia pileus and Aurelia aurita were obtained from van der Veer \& Sadée (1984) 
and van der Veer \& Oorthuysen (1985). These rates are based on biomass data, which were estimated from abundance figures combined with diameter-weight relations. For these relations, published data were used, which showed good correspondence with a number of determinations by the author. For a detailed description see van der Veer \& Sadée (1984) and van der Veer \& Oorthuysen (1985). The resulting total consumption of the 2 species, in $\mathrm{g}$ of carbon per $1000 \mathrm{~m}^{3}$ per day $\left(\mathrm{g} C 1000 \mathrm{~m}^{-3} \mathrm{~d}^{-1}\right)$, is shown in Fig. 6. This

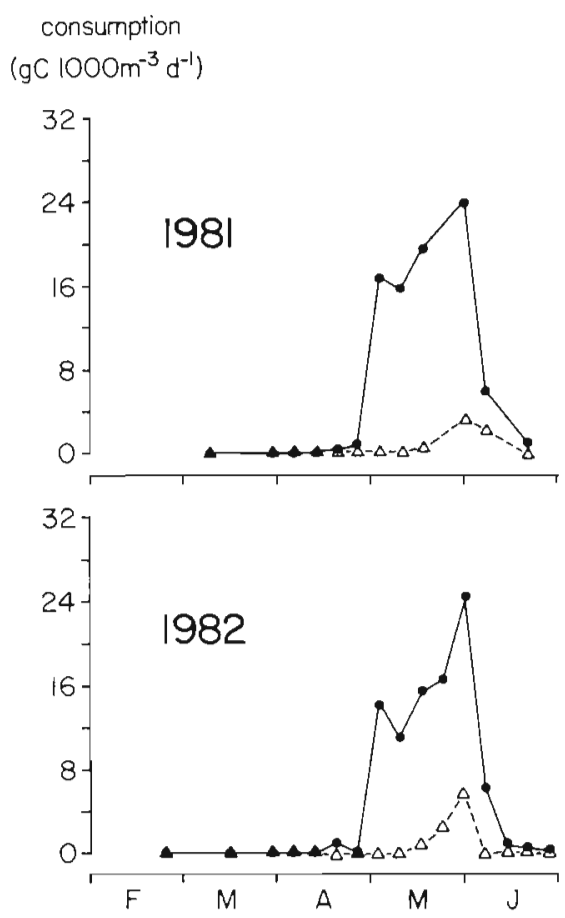

Fig. 6. Estimated total daily consumption $\left(\mathrm{g} \mathrm{C} 1000 \mathrm{~m}^{-3} \mathrm{~d}^{-1}\right)$ by the predatory coelenterates Pleurobrachia pileus (-) and Aurelia aurita (--) near the entrance of the Wadden Sea in 1981 and 1982

figure is probably an overestimation, because previous work revealed that $P$. pileus does not seem to encounter optimal feeding conditions in the coastal zone (van der Veer \& Sadée 1984). By assuming a mean carbon content of $0.7 \mathrm{mg} C$ per flatfish larva (Kuipers pers. comm.), the total biomass of flatfish larvae (mg C $1000 \mathrm{~m}^{-3}$ ), can be computed for the $3 \mathrm{yr}$ (Fig. 7). At the end of April peak values of between 100 and $320 \mathrm{mg} \mathrm{C}$ $1000 \mathrm{~m}^{-3}$ are reached, mainly consisting of flounder larvae. Other larval fish species present in the same period, mainly herring and sprat, represent a smaller biomass of about $50 \mathrm{mg} \mathrm{C} 1000 \mathrm{~m}^{-3}$ (Corten \& van de Kamp 1979, Kuipers pers. comm.). Together with the main food source of the coelenterates, the zooplankton,

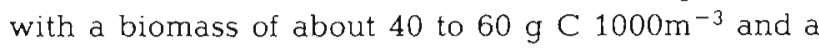
production of about $0.10 \mathrm{~d}^{-1}$ in this area in the begin-

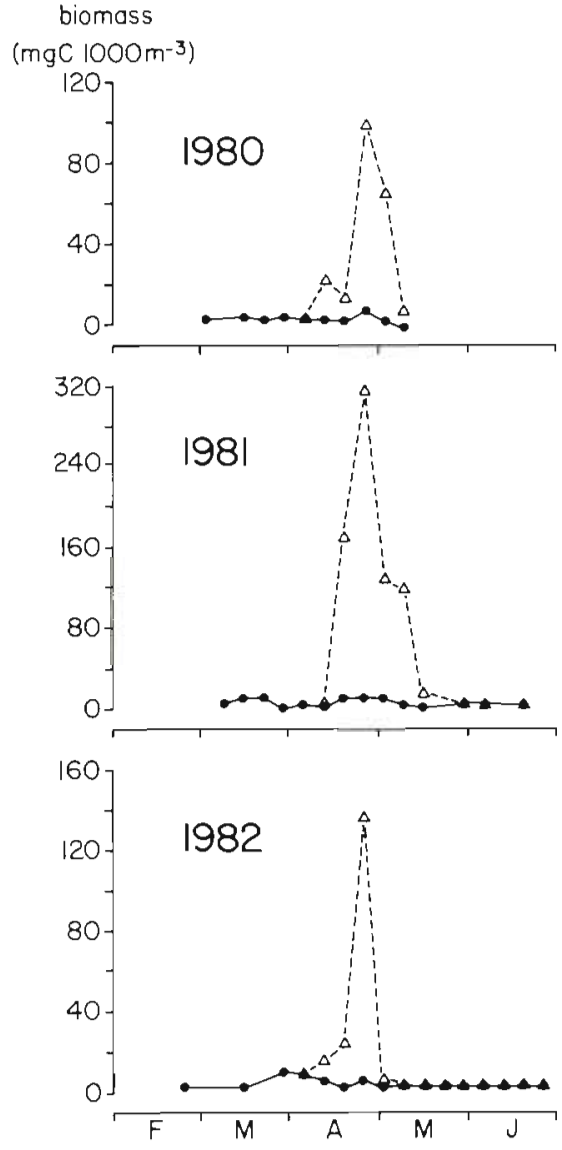

Fig. 7. Pleuronectes platessa and Platichthys flesus. Mean tidal biomass ( $\mathrm{mg} \mathrm{C} 1000 \mathrm{~m}^{-3}$ ) of plaice (-) and flounder (---) larvae near the entrance of the Wadden Sea in 1980 , 1981 and 1982

ning of May (Fransz 1981), it is clear that consumption by coelenterates appears to be very large compared with the standing stock of the food resources. According to this approach a virtual extinction of the flatfish larvae after the end of April through coelenterate predation might well be possible.

This predation process will not be limited to the Wadden Sea entrance. Flatfish larvae, entering the Wadden Sea on the tidal currents, will already have met the screen of predatory coelenterates somewhere offshore in the coastal area. Therefore, the actual predation process can be expected to last much longer than the period between larval immigration and subsequent settling on the tidal flats as measured within the boundary of the nursery.

\section{Impact of coelenterate predation on larval flatfish populations}

Coelenterate predation can affect the recruitment of a fish species. In Kiel Bight the scyphomedusal jelly- 
fish Aurelia aurita consumes large amounts of yolk-sac herring larvae and reduces the population size considerably (Möller 1984). For flatfish larvae, predation by coelenterates seems to be dependent on larval size, at least as far as $A$. aurita is concerned (Bailey 1984). Because of their smaller size, flounder larvae will be more susceptible to predation than plaice larvae. Plaice and flounder also differ as to their behaviour after an encounter with a predator. Plaice larvae are more reactive than flounder (Bailey 1984), which may decrease the risk of predation.

A major impact of coelenterate predation on the recruitment of plaice seems unlikely, because in all 3 yr immigration of the larvae started in late February and had thus already lasted for 2 mo when the outburst of coelenterates occurred. Therefore, most of the larvae would have passed largely unaffected and have settled on the tidal flats of the Wadden Sea before serious coelenterate predation started. The onset of the coelenterate outburst occurs at approximately the same time every year. A significant moderating effect on between-year fluctuations of the larval stock can only by expected if the timing of larval immigration is related to the abundance of the year-class. This has indeed been suggested by Zijlstra et al. (1982) and by this study; larger year-classes show a somewhat delayed arrival, from March to April. Therefore, the coelenterate-induced mortality might have a densitydependent component, reducing the between yearclass fluctuations.

For flounder the processes determining year-class strength are less known. Neither for the pelagic nor for the demersal phase have detailed studies been carried out. Larval immigration of flounder shows a regular pattern similar to that of plaice in all 3 yr. However, since it starts 1 mo later, the explosive outburst of predatory coelenterates coincides with maximum flounder immigration. Moreover, flounder larvae may be more exposed to predation because of their smaller size. A much greater impact on flounder is suggested by the larger numbers of larvae found in coelenterates stomachs. However, more insight into the fate of flounder after settlement is required before the precise effect can be evaluated.

Acknowledgements. Thanks are due to M. J. N. Bergman, R. M. Brocades Zaalberg, H. van Garderen, W. Oorthuysen and C. F. M. Sadée for assistance during sampling, to J. J. Zijlstra for his guidance and to G. P. Baerends, F. Creutzberg, N. Daan, B. R. Kuipers, P. de Wolf and Mrs. G. van der Wolf for critical reading of the manuscript. These investigations were supported by the Foundation for Fundamental Biological Research (BION), which is subsidized by the Netherlands Organization for the Advancernent of Pure Research (ZWO).

\section{LITERATURE CITED}

Arai, M. N., Hay, E. (1982). Predation by medusae on Pacific herring (Clupea harengus pallasi] larvae. Can. J. Fish. Aquat. Sci. 39: 1537-1540

Baan, S. M. van der (1980a). Hydromedusae in the surface water around the 'Texel' lightvessel. Interne Verslagen Nederlands Instituut voor Onderzoek der Zee, Texel, 1980-1, p. $1-33$

Baan, S. M. van der (1980b). Overzicht macro-plankton onderzoek bij het lichtschip 'Texel', 1961-1966. Interne Verslagen Nederlands Instituut voor Onderzoek der Zee, Texel, 1980-7, p. 1-20.

Baan, S. M. van der (1980c). The seasonal occurrence of scyphomedusae in surface waters near the 'Texel' lightvessel. Interne Verslagen Nederlands Instituut voor Onderzoek der Zee, Texel, 1980-9, p. 1-18

Bailey, K. M. (1984). Comparison of laboratory rates of predation on five species of marine fish larvae by three planktonic invertebrates: effects of larval size on vulnerability. Mar. Biol. 79: 303-309

Bailey, K. M. Batty, R. S. (1983). A laboratory study of predation by Aurelia aurita on larval herring (Clupea harengus): experimental observations compared with model predictions. Mar. Biol. 72: 295-301

Bergman, M. J. N., Spliethoff, P. J., Veer, H. W van der (1980). De ecologie van 0-groep schol (Pleuronectes platessa L.) op het Balgzand. Deel I: Aantalsverloop, verspreiding en getijdenmigratie. Interne Verslagen Nederlands Instituut voor Onderzoek der Zee, Texel, 1980-9, p. $1-40$

Corten, A., Kamp, G. van de (1979). Abundance of herring larvae in the Dutch Wadden Sea as a possible indication of recruitment strength. Coun. Meet. int. Coun. Explor. Sea, C. M.-ICES/H: 26, p. 1-5

Creutzberg, F., Fonds, M. (1971). The seasonal variation in the distribution of some demersal fish species in the Dutch Wadden Sea. Thassia jugosl. 7: 13-23

Creutzberg, F., Eltink, A. T. G. W., Noort, G. J. van (1978). The migration of plaice larvae Pleuronectes platessa into the western Wadden Sea. In: McLusky, D. S., Berry, A. J. (ed.), Physiology and behaviour of marine organisms, Proc. 12th Europ. mar. biol. Symp. Pergamon Press, Oxford, New York, p. 243-251

Daan, N. (1976). Some preliminary investigations into predation on fish eggs and larvae in the Southem North Sea. Coun. Meet. int. Coun. Explor. Sea C. M.-ICES/L: 15, p. $1-5$

Daan, N., Rijnsdorp, A. D., Overbeeke, G. R. (1984). Predation of plaice and cod eggs by North Sea herring. Coun. Meet. int. Coun. Explor. Sea C. M.-ICES/L: 13, p. 1-16

Dapper, R. (1978), De Balgzand scholgegevens 1975, 1976, 1977. Interne Verslagen Nederlands Instituut voor Onderzoek der Zee, Texel 1978-12, p. 1-53

Elliot, J. M. (1977). Some methods for the statistical analysis of samples of benthic invertebrates. Freshwat. biol. Ass., Scient. Publ. No. 25, p. 1-160

Fransz, H. G. (1981). Quantitative data on the plankton of the Wadden Sea proper. In: Dankers, N., Kühl, H., Wolff, W. J. (ed.) Invertebrates of the Wadden Sea. Balkema, Rotterdam, p. 125-133

Fraser, J. H. (1969). Experimental feeding of some medusae and chaetognatha. J. Fish. Res. Bd Can. 26: 1743-1762

Greve, W. (1970). Cultivation experiments on North Sea ctenophores. Helgoländer Meeresunters. 20: 304-317

Greve, W. (1972). Okologische Untersuchungen an Pleurob- 
rachia pileus 2. Laboratoriumuntersuchungen. Helgoländer Meeresunters. 23: 141-164

Harding, D., Nichols, J. H., Tungate, D. S. (1978). The spawning of plaice (Pleuronectes platessa L.) in the southern North Sea and English Channel. Rapp. P.-v. Réun. Cons. int. Explor. Mer 172: 102-113

Houghton, R. G., Harding, D. (1976). The plaice of the English Channel: spawning and migration. J. Cons, int. Explor. Mer 36: 229-239

Kremer, P. (1976). Population dynamics and ecological energetics of a pulsed predator, the ctenophore Mnemiopsis leidyi. In: Wiley, M. (ed.) Estuarine processes, Vol I, Uses, stress and adaptation to the estuary. Academic Press, New York, p. 197-215

Lebour, M. (1922). The food of plankton organisms. J. mar. biol. Ass. U.K. 12; 644-677

Lebour, M. (1923). The food of plankton organisms II. J. mar. biol. Ass. U.K. 13: 70-92

Lockwood, S. J. (1973). Weight and length changes of 0-group plaice (Pleuronectes platessa $L$.) after preservation in $4 \%$ neutral formalin. J. Cons. int. Explor. Mer 35: 100-101

Möller, H. (1980a). Scyphomedusae as predators and food competitors of larval fish. Ber. dt. wiss. Kommn. Meeresforsch. 28: $90-100$

Möller, H. (1980b). Population dynamics of Aurelia aurita in Kiel Bight, Germany (FRG). Mar. Biol. 60: 123-128

Möller, H. (1984). Reduction of a larval herring population by jellyfish predator. Science 224: 621-622

Postma, H. (1954). Hydrography of the Dutch Wadden Sea. Archs néerl. Zool. 10: 405-511

Reeve, M. R., Walter, M. A. (1978). Nutritional ecology of ctenophores. A review of recent research. In: Russell, F. S., Younge, $M$. (ed.) Advances in marine biology, Vol 15. Academic Press, London, p. 249-289
Seip, P., Seip-Ottema, M. (1981). De betekenis van predatie voor de dichtheidsafname van de calanoide copepoden in juni/juli in de zuidelijke bocht van de Noordzee. Interne Verslagen Nederlands Instituut voor Onderzoek der Zee, Texel, 1981-3, p. 1-66

Smith, P. E., Counts, R. C., Clutter, R. I. (1968). Changes in filtering efficiency of plankton nets due to clogging under tow. J. Cons. perm. int. Explor, Mer 32: 232-248

Talbot, J. W. (1976). The dispersal of plaice eggs and larvae in the Southern Bight of the North Sea. J. Cons. int. Explor. Mer 37: 221-248

Talbot, J. W. (1978). Changes in plaice larval dispersal in the last fifteen years. Rapp. P.-v. Réun. Cons. int. Explor. Mer 172: $114-123$

Tungate, D. S. (1975). The distribution and abundance of chaetognaths and the ctenophore Pleurobrachia pileus in the southern North Sea in 1968 and their importance as predators on plaice larvae and eggs. Fish. Lab. Tech. Rep. Ser. 18. Fish. Lab. Lowestoft, Suffolk, p. 1-31

Veer, H. W. van der, Sadée, C. F. M. (1984). The seasonal occurrence of the ctenophore Pleurobrachia pileus in the western Dutch Wadden Sea. Mar. Biol. 79: 219-227

Veer, H. W. van der, Oorthuysen, W. (1985). Abundance, growth and food demand of the scyphomedusa Aurelia aurita in the western Dutch Wadden Sea. Neth. J. Sea Res. 19: $38-44$

Zijlstra, J. J. (1972). On the importance of the Wadden Sea as a nursery area in relation to the conservation of the southern North Sea fishery resources. Symp. zool. Soc. Lond. 29: 233-258

Zijlstra, J. J., Dapper, R., Witte, J. Y. (1982). Settlement, growth and mortality of post-larval plaice (Pleuronectes platessa) in the western Wadden Sea. Neth. J. Sea. Res. 15: $250-272$ 